\title{
Yield and ion content in maize irrigated with saline water in a continuous or alternating system
}

\author{
Produtividade e teores de íons no milho irrigado com águas salinas de forma contínua ou alternada
}

\author{
Felipe de Sousa Barbosa ${ }^{\mathrm{I}}$ Claudivan Feitosa de Lacerda ${ }^{\mathrm{I} *}$ Hans Raj Gheyi ${ }^{\mathrm{II}}$ Gabriel Castro Farias ${ }^{\mathrm{I}}$ \\ Ricardo José da Costa Silva Júnior ${ }^{I}$ Yara Araújo Lage ${ }^{I}$ Fernando Felipe Ferreyra Hernandez ${ }^{\text {II }}$
}

\begin{abstract}
Irrigation with water containing salt in excess can affect crop development. However, management strategies can be used in order to reduce the impacts of salinity, providing increased efficiency in the use of good quality water. The objective of this research was to study the effects of use of high salinity water for irrigation, in continuous or cyclic manner, on vegetative growth, yield, and accumulation of ions in maize plants. Two experiments were conducted during the months from October to January of the years 2008/2009 and 2009/ 2010 , in the same area, adopting a completely randomized block design with four replications. Irrigation was performed with three types of water with electrical conductivities (ECw) of 0.8 (A1), 2.25 (A2) and 4.5 (A3) $d S \mathrm{~m}^{-1}$, combined in seven treatments including the control with low salinity water (A1) throughout the crop cycle (T1). Saline waters (A2 and A3) were applied continuously (T2 and T5) or in a cyclic way, the latter being formed by six irrigations with Al water followed by six irrigations by eitherA2 or A3 water, starting with A1 at sowing (T3 and T6) or 6 irrigations with A2 or A3 water followed by 6 irrigations with A1 water (T4 and T7). The use of low and high salinity water resulted in lower accumulation of potentially toxic ions ( $\mathrm{Na}$ and $\mathrm{Cl}$ ) and improvement in the $\mathrm{Na} / \mathrm{K}$ balance in the shoots of maize plants. Application of saline water in a cyclic way also allows the substitution of about $50 \%$ of water of low salinity in irrigation, without negative impacts on maize yield.
\end{abstract}

Key words: Zea mays L., salt tolerance, irrigation management. RESUMO

A irrigação com águas que contenham sais em excesso pode afetar de forma negativa o desenvolvimento das culturas. No entanto, estratégias de manejo devem ser utilizadas de modo a reduzir os impactos da salinidade, proporcionando aumento na eficiência do uso de água de boa qualidade. $O$ objetivo deste trabalho consistiu em estudar os efeitos de uso de água de alta salinidade na irrigação, de forma contínua ou cíclica, sobre o crescimento vegetativo, a produtividade e o acúmulo de íons em plantas de milho. Foram realizados dois experimentos durante os meses de outubro a janeiro, em 2008/ 2009 e 2009/2010, na mesma área, adotando-se um delineamento experimental em blocos casualizados, com quatro repetições. A irrigação foi realizada com três tipos de água com condutividade elétrica (CEa) de 0,8 (A1), 2,25 (A2) e 4,5 (A3) $d S \mathrm{~m}^{-1}$, combinadas em sete tratamentos, incluindo o controle com água de baixa salinidade (A1) durante todo o ciclo (T1). As águas salinas A2 e A3 foram aplicadas de forma contínua (T2 e T5) ou cíclica, sendo esse último manejo formado por seis irrigações com A1, seguidas de seis irrigações com A2 ou A3 (T3 e T6), iniciando com Al na semeadura ou seis irrigações com A2 ou A3, seguidas por seis irrigações com Al (T4 e T7). O uso cíclico de águas de baixa e alta salinidade resultou em menor absorção de íons potencialmente tóxicos ( $\mathrm{Na}$ e $\mathrm{Cl}$ ) $e$ melhoria no balanço $\mathrm{Na} / \mathrm{K}$ na parte aérea das plantas de milho. A aplicação de água salina de forma cíclica permitiu também a substituição de cerca de $50 \%$ de água de baixa salinidade na irrigação, sem impactos negativos sobre a produtividade do milho.

Palavras-chave: Zea mays L., tolerância à salinidade, manejo de irrigação.

\section{INTRODUCTION}

The semi-arid region of northeast Brazil, besides having a scarcity of water resources to meet

\footnotetext{
IDepartamento de Engenharia Agrícola, Universidade Federal do Ceará (UFC), Bloco 804, Campus do Pici, 60455-970, Fortaleza, CE, Brasil. E-mail: cfeitosa@ufc.br. *Autor para correspondência.

IIDepartamento de Engenharia Agrícola, Universidade Federal de Campina Grande (UFCG), Campina Grande, PB, Brasil.

IIIDepartamento de Ciências do Solo, UFC, Fortaleza, CE, Brasil.
} 
the needs of the population (domestic, industrial, irrigation, etc.), is also faced with the presence of high salt content in most water sources. Among other factors, this problem is related to high evaporation and low precipitation, associated with the characteristics of the parent material of the soil (GHEYI et al., 2010).

Irrigated agriculture depends on the quantity and quality of water. The aspect of quality has been neglected in the past, so the sources of good water quality have decreased significantly due to intensive use. Thus, one has to resort to low quality water for implementation of new projects. In the Northeast, the available water sources, especially underground, are of poor quality. According to SILVA et al. (2007) about 23,000 wells were drilled in Ceará until 2003. Around 63\% of these were in the crystalline basement, $29 \%$ in sedimentary rocks and the remainder in karst and alluvial formations. Also according to these authors, the crystalline waters of the wells have a higher salt content than the sediment lithology.

In case of surface water sources the differences in salinity arise due to higher or lower dilution with rain water which the reservoir receives. Evaporation is also responsible for the salinization of groundwater stored in the alluvial areas, given that the salts accumulated in small depressions in the dry season are carried away during the rainy season to the surrounding areas. The salts in the reservoirs are drawn mainly from the rocks and their products of weathering (SILVA et al., 2007).

The successful use of saline water requires the selection of salt tolerant crops, the choice of the appropriate irrigation system and the application of suitable water management strategies (MALASH et al., 2008). Among the alternatives for the use of saline water in irrigated agriculture, include management techniques such as drainage and leaching of salts, the use of salt tolerant crops, or even crop rotation, mixing of irrigation-water of different salt concentrations, or the use of saline water only in the growth and development stages in which crop has a higher degree of tolerance (MURTAZA et al., 2006; BEZERRA et al. 2010; GARCIA et al., 2011). Another alternative that could reduce the concentration of salts and increase the availability of water for irrigation is cyclic use of water sources with different concentrations of salts (YADAV et al., 2007; MALASH et al., 2008). This strategy can result in lesser accumulation of salts in soil thereby contributing to reduce the impacts of saline stress on plant growth and increases the efficiency of use of good quality water.

This study seeks to evaluate the effects of use of high salinity water for irrigation, either continuously or in cyclic way, on vegetative growth, yield, and accumulation of ions in maize plants.

\section{MATERIAL AND METHODS}

The research was carried out in the experimental area of the Laboratory of Hydraulics and Irrigation, Campus of Pici, Universidade Federal do Ceará, in Fortaleza ( $3^{\circ} 45^{\prime}$ S, $38^{\circ} 33^{\prime} \mathrm{W}$, and $19 \mathrm{~m}$ above sea level), Ceará, in the dry season from October to January, 2008/2009, and repeated during the same months in 2009/2010.

According to the classification of Köppen the experimental area is located in a region of Aw' climate. Mean air temperature, relative humidity and total rainfall obtained during the study period in dry seasons of 2008/2009 and 2009/2010 were respectively: 27.8 and $27.6^{\circ} \mathrm{C}, 71.5$ and $72.8 \% ; 23$ and $74 \mathrm{~mm}$. The soil is Alfissol, having following physical and chemical characteristics in the $0-30 \mathrm{~cm}$ depth: sandy loam texture, bulk density - $1.4 \mathrm{~kg} \mathrm{dm}^{-3}, \mathrm{pH}-5.4, \mathrm{EC}-0.20 \mathrm{dS} \mathrm{m}^{-1}$, and $\mathrm{Ca}, \mathrm{Mg}, \mathrm{K}$ and $\mathrm{Na}, 0.8,0.9,0.09$ and $0.22 \mathrm{cmol}_{\mathrm{c}} \mathrm{dm}^{-3}$ respectively. In May 2008, lime equivalent to $2.0 \mathrm{Mg}$ $\mathrm{ha}^{-1}$ was incorporated with a plow and a harrow.

The experimental design was in randomized blocks with seven treatments and four replications. The following treatments were studied: T1- Use of low salinity water $\left(\mathrm{A} 1-0.8 \mathrm{dS} \mathrm{m} \mathrm{m}^{-1}\right)$ throughout the crop cycle, $\mathrm{T} 2$ - use of water with ECw of 2.25 (A2), T3 - using in cyclic way A1 and A2 waters (6 irrigations with A1 followed by 6 irrigations with A2 water), T4 - using in cyclic way A2 and A1 waters (6 irrigations with A2 followed by 6 irrigations with A1 water), T5 - use of water with $\mathrm{ECw}$ of $4.5 \mathrm{dS} \mathrm{m}^{-1}$ (A3) throughout the crop cycle, T6 - using in cyclic way A1 and A3 waters ( 6 irrigations with $\mathrm{A} 1$ followed by 6 irrigations with $\mathrm{A} 3$ water) and $\mathrm{T} 7$ - using in cyclic way $\mathrm{A} 3$ and $\mathrm{A} 1$ waters (6 irrigations with A3 followed by 6 irrigations with A1 waters). Each plot had dimensions of $3 \times 3.5 \mathrm{~m}$ with 5 rows of $3 \mathrm{~m}$ in length.

Low salinity water (A1) was obtained from a well located in the experimental area having ECw of $0.8 \mathrm{dS} \mathrm{m}^{-1}$ while $\mathrm{A} 2$ (ECw $2.25 \mathrm{dS} \mathrm{m}^{-1}$ ) and $\mathrm{A} 3$ (ECw $4.5 \mathrm{dS}$ $\mathrm{m}^{-1}$ ) were prepared by adding $\mathrm{NaCl}, \mathrm{CaCl}_{2} \cdot 2 \mathrm{H}_{2} \mathrm{O}$ and $\mathrm{MgCl}_{2} .6 \mathrm{H}_{2} \mathrm{O}$ salts in equivalent proportion of 7:2:1 in A1 water according to relationship between $\mathrm{ECw}$ and concentration $\left(\mathrm{mmol}_{\mathrm{c}} \mathrm{L}^{-1}=\mathrm{ECwx} 10\right)$.

Seeds of maize (Zea mays L.) hybrid AG 1051 were planted in rows $0.7 \mathrm{~m}$ apart $\left(5\right.$ seeds $\left.\mathrm{m}^{-1}\right)$. Manual weeding was done along the crop cycle with preventive control of pests and diseases. Fertilizer doses of 90,90 and $60 \mathrm{~kg} \mathrm{ha}^{-1}$ of $\mathrm{N}, \mathrm{P}_{2} \mathrm{O}_{5}$ and $\mathrm{K}_{2} \mathrm{O}$, were applied using respectively urea, superphosphate and potassium chloride. The dose of $\mathrm{N}$ was divided into three equal parts and applied at planting, at 25 and 40 days after planting (DAP), the $\mathrm{P}$ was applied only as basal dose, 
while the dose of $\mathrm{K}$ was divided into two equal parts, half at planting and the other half as topdressing at 25DAP.

Each plot was irrigated with the respective water treatment three days before sowing. The water was applied in leveled $3 \mathrm{~m}$ long closed end furrows and the irrigation depths were applied according to crop water requirement based on the values of reference evapotranspiration (ETo) obtained by the method of the Class A pan, and the crop coefficient (Kc). To avoid excessive accumulation of salts in the soil, irrigation water depth was applied using a leaching fraction of 0.15 in all treatments. The irrigation depths and the contribution of each type of water used were recorded and analyzed at the end.

At the end of each crop cycle, which occurred at 90DAP, 15 plants in each plot (central row) were sampled to quantify dry matter of shoots, 1000 grain weight, yield and harvest index. Samples of vegetative parts (stems, leaves and sheaths), collected at the end of the second crop were used to assess the levels of $\mathrm{Na}, \mathrm{K}$ and $\mathrm{Ca}$.

The data of each experiment was individually analyzed and differences among treatments were tested by analysis of variance and means were compared using test of Tukey at $\mathrm{P}<0.05$, by SAEG/ UFV software tool.

\section{RESULTS AND DISCUSSION}

Means for shoot dry matter, 1000 grain weight, yield and harvest index of maize plants under different management of irrigation with saline water during 2008/2009 and 2009/2010 crop cycles are presented in table 1 . There was significant difference for the yield in the first crop (2008/2009), and the lowest values were found in plants that were subjected to irrigation with high salinity water of EC $4.5 \mathrm{dS} \mathrm{m}^{-1}$ during the whole cycle (T5) or when this water was applied during germination and early growth (T7). Yield decrease was related to the reduction of grain size, since the 1000 grain weight was also reduced in treatment with continuous use of high salinity water.

LACERDA et al. (2011) under same edaphoclimatic conditions found $29 \%$ reduction in yield when maize plants were irrigated continuously with water of ECw $5.0 \mathrm{dS} \mathrm{m} \mathrm{m}^{-1}$, and similar reduction was observed in present study in $\mathrm{T} 5$ with ECw of $4.5 \mathrm{dS} \mathrm{m}^{-1}$. BLANCO et al. (2008) found decreases above $50 \%$ in

Table 1 - Means for shoot dry matter (SDM), 1000 grain weight (G1000), yield and harvest index (HI) of maize plants under different irrigation management with saline water during 2008-2009 and 2009-2010 crop cycles. Fortaleza, CE.

\begin{tabular}{|c|c|c|c|c|}
\hline Treatments $^{*}$ & $\begin{array}{c}\text { SDM } \\
\text { g plant }^{-1}\end{array}$ & $\begin{array}{l}\text { G1000 } \\
\text { (g) }\end{array}$ & $\begin{array}{c}\text { Yield } \\
\left(\mathrm{kg} \mathrm{ha}^{-1}\right)\end{array}$ & $\begin{array}{l}\mathrm{HI} \\
(\%)\end{array}$ \\
\hline \multicolumn{5}{|c|}{ - } \\
\hline T1 & $197.83 \mathrm{a}^{* *}$ & $255 \mathrm{ab}$ & $8480.46 \mathrm{a}^{1}$ & $60.0 \mathrm{a}$ \\
\hline $\mathrm{T} 2$ & $205.07 \mathrm{a}$ & 270 a & $8609.28 \mathrm{a}$ & $58.8 \mathrm{a}$ \\
\hline $\mathrm{T} 3$ & $194.62 \mathrm{a}$ & $267 \mathrm{a}$ & $8448.57 \mathrm{a}$ & $60.8 \mathrm{a}$ \\
\hline $\mathrm{T} 4$ & $196.98 \mathrm{a}$ & $261 \mathrm{a}$ & $8525.95 \mathrm{a}$ & $60.6 \mathrm{a}$ \\
\hline T5 & $155.29 \mathrm{a}$ & $223 \mathrm{~b}$ & $6067.62 \mathrm{~b}$ & $54.7 \mathrm{a}$ \\
\hline T6 & 204.24 a & $255 \mathrm{ab}$ & $8543.81 \mathrm{a}$ & $58.6 \mathrm{a}$ \\
\hline T7 & $180.32 \mathrm{a}$ & $248 \mathrm{ab}$ & $7139.05 \mathrm{ab}$ & $55.4 \mathrm{a}$ \\
\hline \multicolumn{5}{|c|}{----II Experiment - Cycle 2009/2010------ } \\
\hline $\mathrm{T} 1$ & $181.45 \mathrm{ab}$ & $230 \mathrm{a}$ & $5994.02 \mathrm{a}$ & $44.7 \mathrm{a}$ \\
\hline $\mathrm{T} 2$ & $184.56 \mathrm{ab}$ & 237 a & $6333.32 \mathrm{a}$ & $45.3 \mathrm{a}$ \\
\hline $\mathrm{T} 3$ & $152.07 \mathrm{~b}$ & $200 \mathrm{a}$ & $4732.17 \mathrm{a}$ & $41.4 \mathrm{a}$ \\
\hline $\mathrm{T} 4$ & $182.54 \mathrm{ab}$ & $224 \mathrm{a}$ & $5791.67 \mathrm{a}$ & $46.8 \mathrm{a}$ \\
\hline T5 & $178.44 \mathrm{ab}$ & $214 \mathrm{a}$ & $5452.40 \mathrm{a}$ & $44.8 \mathrm{a}$ \\
\hline T6 & $194,07 \mathrm{ab}$ & 226 a & $6648.82 \mathrm{a}$ & $41.6 \mathrm{a}$ \\
\hline T7 & $200,53 \mathrm{a}$ & $228 \mathrm{a}$ & $6267.85 \mathrm{a}$ & $45, .7 \mathrm{a}$ \\
\hline
\end{tabular}

* T1: Use of low salinity water with EC of $0.8 \mathrm{dS} \mathrm{m} \mathrm{m}^{-1}$ (A1), throughout the cycle; T2: water with EC of $2.25 \mathrm{dS} \mathrm{m}^{-1}$ (A2), throughout the cycle; T3: using in cyclic way A1 and A2 waters (6 irrigations with A1 followed by 6 irrigations with A2) during the crop cycle; T4: using in cyclic way A2 and A1 waters (6 irrigations with the A2, followed by 6 irrigation with A1) during the crop cycle; T5: water with EC of 4.5dS $\mathrm{m}^{-1}$ (A3) during the entire cycle; T6: using in cyclic way A1 and A3 waters (6 irrigations with A1 followed by 6 irrigations with A3) during the crop cycle; T7: using in cyclic way A3 and A1 waters (6 irrigations with A3 followed by 6 irrigations with A1) during the crop cycle. ** Means not followed by the same letter in columns differ statistically by Tukey test $(\mathrm{P}<0,05)$. 
yield of maize when irrigated continuously with saline water of $4.5 \mathrm{dS} \mathrm{m} \mathrm{m}^{-1}$ electrical conductivity but in this case the study was conducted under greenhouse conditions in pots which results in higher accumulation of salts in the root zone.

In the second experiment (2009/2010), however, the effects of treatments on yield were not significant (Table 1), which can be explained, at least in part, by higher rainfall in late 2009 and early 2010, which might have reduced the impact of salinity on maize yield. The total precipitation in 2008/2009 crop cycle was $51 \mathrm{~mm}$ less than $2009 / 2010$ crop cycle, though in the latter case the rains $(74 \mathrm{~mm})$ were concentrated in the final stage of crop cycle (reproductive stage). According to MITTLER (2006) the salt tolerance of plants varies with species but also depends on factors such as soil and ambient conditions and plants suffer much more in dry and hot environment. In the present study the rains occurred during the second crop cycle might have promoted partial dilution of salts accumulated in soil reducing the osmotic effects of saline stress.

In none of the crop cycles the effects of treatments on harvest index were significant, but the values were higher in 2008/2009 than those observed in second cycle (Table 1). The mean values found 58.4 and 44.3 respectively, are with in the range of values observed for maize crop which is from 0.30 to 0.60 (DOORENBOS \& KASSAM, 1994). The nonexistence of effects of salinity on harvest index was also verified by BLANCO et al. (2008). This result, however, is contrary to observed by other authors, which indicate that salinity besides affecting the growth and yield may also alter the partition of photoassimilates in different parts (AQUINO et al., 2007).
The most common effect of salinity on plants is related to the reduction of carbon assimilation and growth inhibition because of the lowering of osmotic potential of the medium and the accumulation of potentially toxic ions in plants (BLANCO et al., 2008). According to CHAUHAN et al. (2007) and YADAV et al. (2007), cyclic use of low and high salinity water can minimize these impacts on soil and plants, and these effects depend on the proportion of different sources of water and the irrigation method used (MALASH et al., 2008). In addition, one should avoid the use of saline water in the early stages of crop growth. Therefore, in the present study beneficial effects of the cyclic use of high and low salinity water indicates that this strategy reduces the osmotic effects of salinity on maize plants. Irrigation depth and contribution of each type of water in different strategies of management of irrigation water during 2008/2009 and 2009/2010 crop cycles are presented in table 2 . The data showed an important aspect in terms of economy of good quality water. Comparing the T1 (irrigation with low salinity water) treatment with the use of high salinity water in a cyclic form (T3, T4, T6 and T7), a replacement ranging from 46 to $53 \%$ of good quality water by high salinity water was observed. In the crop cycle 2008/2009 the lowest maize yield was observed in $\mathrm{T} 5$ and $\mathrm{T} 7$, with continuous use of high salinity water or when this water source was used in the initial stages of the crop cycle, respectively (Table 1). This demonstrates the effectiveness of the strategy of cyclic use of waters of different salinity and should take into account the higher sensitivity of crop during seed germination and early growth, as observed by other authors (MURTAZA et al., 2006; CHAUHAN et al., 2007; NEVES et al., 2010).

Table 2 - Irrigation depth $(\mathrm{mm})$ and contribution of each type of water under different management of irrigation (treatments) during 2008/2009 and 2009/2010. Fortaleza, CE.

\begin{tabular}{|c|c|c|c|c|c|c|}
\hline \multirow{3}{*}{ Treatment } & \multirow{2}{*}{\multicolumn{3}{|c|}{ 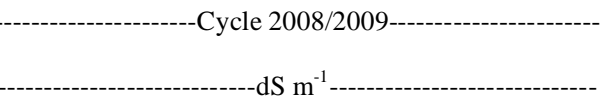 }} & \multirow{2}{*}{\multicolumn{3}{|c|}{----------------------Cycle 2009/2010--------------- }} \\
\hline & & & & & & \\
\hline & 0.8 & 2.25 & 4.5 & 0.8 & 2.25 & 4.5 \\
\hline $\mathrm{T} 1$ & 589.5 & -- & -- & 571.8 & -- & -- \\
\hline $\mathrm{T} 2$ & -- & 589.5 & -- & -- & 571.8 & -- \\
\hline $\mathrm{T} 3$ & 315.7 & 273.8 & -- & 301.5 & 270.3 & -- \\
\hline $\mathrm{T} 4$ & 273.8 & 315.7 & -- & 270.3 & 301.5 & -- \\
\hline T5 & -- & -- & 589.5 & -- & -- & 571.8 \\
\hline T6 & 315.7 & -- & 273.8 & 301.5 & -- & 270.3 \\
\hline $\mathrm{T} 7$ & 273.8 & -- & 315.7 & 270.3 & -- & 301.5 \\
\hline
\end{tabular}

* For description of treatments see legend of table 1. 
Mean contents of $\mathrm{Na}, \mathrm{Cl}, \mathrm{K}$ and $\mathrm{Ca}$ in leaf, sheath and stem, $\mathrm{Na} / \mathrm{K}$ ratio in leaf, sheath and stem, and stem/leaf ratios for $\mathrm{Na}$ and $\mathrm{K}$ in the maize plants grown under different salinity levels of irrigation water during the crop cycle 2009/2010 are presented in table 3 . The reduced growth and yield of crops under salinity conditions could be related, in part, to the accumulation of potentially toxic ions such as $\mathrm{Na}$ and $\mathrm{Cl}$, as well as by inhibiting the absorption of essential nutrients. In this study, it was observed that the salts applied via irrigation water significantly affected the contents of $\mathrm{Na}, \mathrm{Cl}, \mathrm{K}$ and $\mathrm{Ca}$ in the shoots of maize plants (Table 3), but these effects depended on irrigation management strategies adopted in each treatment. The highest concentration of $\mathrm{Na}$ and $\mathrm{Cl}$ in leaf sheaths and stem were found when the maize plants were irrigated throughout the cycle with high salinity water (T5). In the treatments which used water with ECw of $2.25 \mathrm{dS} \mathrm{m}^{-1}$ either continuously or in cyclic form (T3, T4, T6 and T7), the levels of Na did not differ from treatment in which only the low salinity (T1) water was used during the crop cycle. These results demonstrate that cyclic use of high and low salinity water reduces the accumulation of $\mathrm{Na}$ and $\mathrm{Cl}$ in the shoots of maize plants, thereby reducing the ionic toxicity on the sites metabolically active in the leaves. This indicates that the alternate application of low salinity water helps to flush excess salts contained in the root zone, promoting the crop development.

The $\mathrm{K}$ is an important element in regulating the osmotic potential of plant cells and it is believed that under conditions of salt stress, the best performance in a certain genotype may be related to their better potassium nutrition (TALEISNIK \& GRUNBERG, 1994). In the present study, K contents in maize leaves were not affected by salts applied through the irrigation water (Table 3). Unlike the leaf, the effects of saline treatments were observed on the concentration of $\mathrm{K}$ in stem and sheath, but the responses were not similar for these two parts of the plant. Compared to treatment with low salinity water (T1), the continuous employment of water of high salinity $\left(4.5 \mathrm{dS} \mathrm{m}^{-1}\right)$ reduced the contents of $\mathrm{K}$ in stem and increased in sheath. AZEVEDO NETO \& TABOSA

Table 3 - Contents of $\mathrm{Na}, \mathrm{Cl}, \mathrm{K}$ and $\mathrm{Ca}$ in leaf, sheath and stem, $\mathrm{Na} / \mathrm{K}$ ratio in leaf, sheath and stem, and stem/leaf ratios for $\mathrm{Na}$ and $\mathrm{K}$ in the maize plants grown under different managements of irrigation (treatments) during 2009/2010 crop cycle. Fortaleza, CE.

\begin{tabular}{|c|c|c|c|c|c|c|}
\hline Treat ${ }^{*}$ & Leaf & Sheath & Stems & Leaf & Sheath & Stems \\
\hline & \multicolumn{3}{|c|}{----------Na $\left(\mathrm{mmol} \mathrm{kg}^{-1}\right)------$} & \multicolumn{3}{|c|}{------ $\mathrm{Cl}\left(\mathrm{mmol} \mathrm{kg}^{-1}\right)$------- } \\
\hline $\mathrm{T} 1$ & $66.6 b^{* *}$ & $19.0 \mathrm{~b}$ & $27.3 \mathrm{~b}$ & $83.2 \mathrm{c}$ & $48.9 \mathrm{~b}$ & $98.2 \mathrm{ab}$ \\
\hline $\mathrm{T} 2$ & $69.0 \mathrm{~b}$ & $42.5 \mathrm{~b}$ & $17.4 \mathrm{~b}$ & $100.4 \mathrm{~b}$ & $72.2 \mathrm{ab}$ & $107.4 \mathrm{ab}$ \\
\hline $\mathrm{T} 3$ & $65.0 \mathrm{~b}$ & $21.1 \mathrm{~b}$ & $52.3 \mathrm{~b}$ & $89.8 \mathrm{bc}$ & $52.5 \mathrm{~b}$ & $95.6 \mathrm{ab}$ \\
\hline $\mathrm{T} 4$ & $62.6 \mathrm{~b}$ & $25.8 \mathrm{~b}$ & $108.2 \mathrm{~b}$ & $96.4 \mathrm{~b}$ & $71.9 \mathrm{ab}$ & $99.6 \mathrm{ab}$ \\
\hline T5 & $104.1 \mathrm{a}$ & $126.4 \mathrm{a}$ & $753.8 \mathrm{a}$ & $115.5 \mathrm{a}$ & $95.9 \mathrm{a}$ & $122.2 \mathrm{a}$ \\
\hline T6 & $68.5 \mathrm{~b}$ & $28.4 \mathrm{~b}$ & $105.9 \mathrm{~b}$ & $96.4 \mathrm{~b}$ & $67.2 \mathrm{~b}$ & $95.1 \mathrm{~b}$ \\
\hline \multirow[t]{2}{*}{$\mathrm{T} 7$} & $66.6 \mathrm{~b}$ & $31.6 \mathrm{~b}$ & $268.9 \mathrm{~b}$ & $96.0 \mathrm{~b}$ & $68.1 \mathrm{~b}$ & $104.4 \mathrm{ab}$ \\
\hline & \multicolumn{3}{|c|}{----------K (mmol kg-1)--------- } & \multicolumn{3}{|c|}{---------Ca $\left(\mathrm{mmol} \mathrm{kg}^{-1}\right)$-------- } \\
\hline $\mathrm{T} 1$ & $409.2 \mathrm{a}$ & $345.8 \mathrm{~b}$ & $716.6 \mathrm{a}$ & $135.0 \mathrm{c}$ & $47.5 \mathrm{a}$ & $27.0 \mathrm{~b}$ \\
\hline $\mathrm{T} 2$ & $382.6 \mathrm{a}$ & $378.5 \mathrm{ab}$ & $600.0 \mathrm{ab}$ & $167.0 \mathrm{abc}$ & $56.5 \mathrm{a}$ & $35.5 \mathrm{ab}$ \\
\hline $\mathrm{T} 3$ & $387.7 \mathrm{a}$ & $332.5 \mathrm{~b}$ & $600.0 \mathrm{ab}$ & $164.0 \mathrm{abc}$ & $56.5 \mathrm{a}$ & $29.0 \mathrm{ab}$ \\
\hline $\mathrm{T} 4$ & $375.5 \mathrm{a}$ & $345.8 \mathrm{~b}$ & $586.2 \mathrm{ab}$ & $137.0 \mathrm{bc}$ & $54.0 \mathrm{a}$ & $30.0 \mathrm{ab}$ \\
\hline T5 & $364.2 \mathrm{a}$ & $467.5 \mathrm{a}$ & $561.6 \mathrm{~b}$ & $186.5 \mathrm{a}$ & $68.5 \mathrm{a}$ & $44.5 \mathrm{a}$ \\
\hline T6 & $365.2 \mathrm{a}$ & $377.5 \mathrm{ab}$ & $560.6 \mathrm{~b}$ & $169.0 \mathrm{ab}$ & $65.5 \mathrm{a}$ & $28.5 \mathrm{ab}$ \\
\hline \multirow[t]{2}{*}{$\mathrm{T} 7$} & $387.7 \mathrm{a}$ & $318.2 \mathrm{~b}$ & $604.6 \mathrm{ab}$ & $159.0 \mathrm{abc}$ & $80.0 \mathrm{a}$ & $36.5 \mathrm{ab}$ \\
\hline & \multicolumn{3}{|c|}{---------------Na/K ratio----------- } & Na stem/ & \multicolumn{2}{|c|}{$\mathrm{K}$ stem/K leaf } \\
\hline $\mathrm{T} 1$ & $0.15 \mathrm{~b}$ & $0.06 \mathrm{~b}$ & $0.04 \mathrm{c}$ & 0.41 & \multicolumn{2}{|c|}{$1.76 \mathrm{a}$} \\
\hline $\mathrm{T} 2$ & $0.19 \mathrm{~b}$ & $0.11 \mathrm{~b}$ & $0.30 \mathrm{~b}$ & 1.83 & \multicolumn{2}{|c|}{$1.62 \mathrm{a}$} \\
\hline $\mathrm{T} 3$ & $0.17 \mathrm{~b}$ & $0.06 \mathrm{~b}$ & $0.09 \mathrm{c}$ & 0.78 & \multicolumn{2}{|c|}{$1.56 \mathrm{a}$} \\
\hline $\mathrm{T} 4$ & $0.16 \mathrm{~b}$ & $0.07 \mathrm{~b}$ & $0.18 \mathrm{c}$ & 1.15 & \multicolumn{2}{|c|}{$1.57 \mathrm{a}$} \\
\hline T5 & $0.29 \mathrm{a}$ & $0.27 \mathrm{a}$ & $1.34 \mathrm{a}$ & 8.65 & \multicolumn{2}{|c|}{$1.55 \mathrm{a}$} \\
\hline T6 & $0.18 \mathrm{~b}$ & $0.08 \mathrm{~b}$ & $0.19 \mathrm{c}$ & 1.51 & \multicolumn{2}{|c|}{$1.54 \mathrm{a}$} \\
\hline $\mathrm{T} 7$ & $0.18 \mathrm{~b}$ & $0.10 \mathrm{~b}$ & $0.44 \mathrm{~b}$ & 3.92 & \multicolumn{2}{|c|}{$1.57 \mathrm{a}$} \\
\hline
\end{tabular}

* For description of treatments see legend of table 1; ** Means not followed by same letter in columns differ statistically by Tukey test $(\mathrm{P}<0,05)$.

Ciência Rural, v.42, n.10, out, 2012. 
(2000) reported results similar to those observed in stem; perhaps the increase in Na concentration of the external ambient causes the decrease in the levels of $\mathrm{K}$ in the tissues of maize plants, and this effect may be related to the competitive relationship between these cations. On the other hand, increased concentrations of $\mathrm{K}$ in the sheath, due to its reduction in the stem in the saline treatments, may be an indicative of a balance mechanism in the concentrations of $\mathrm{Na}$ and $\mathrm{K}$ for the leaf, i.e, at high concentrations of toxic ions, the highest amount of $\mathrm{K}$ is translocated to the leaf sheath and then to the leaf blades (AQUINO et al., 2007).

Soil salinity significantly affected the contents of $\mathrm{Ca}$ in the leaf and stem, but did not affect their levels in the sheath (Table 3). The highest content of Ca was observed in the treatment under saline water, especially where water with high salinity was applied continuously. This behavior is probably due to the fact that one of the constituent of the salts used in preparation of saline water was calcium chloride, which must have provided the crop with calcium. These results differ from those reported by other authors that observed reduction in calcium contents in the shoots of salt-stressed maize plants (AZEVEDO NETO \& TABOSA, 2000; GARCIA et al., 2007). However, these authors used saline water prepared only with $\mathrm{NaCl}$, and not a mixture of salts as used in this study.

$\mathrm{The} \mathrm{Na} / \mathrm{K}$ ratio in leaf blade and leaf sheath was higher when high salinity water was used continuously (T5), but no significant differences were observed among treatments (Table 3). Values ??in stem were higher when saline waters were used continuously (T2 and T5) and when high salinity water was used in the initial phase of the crop cycle (T7), while no differences were verified among the treatments with cyclic use and treatment of low salinity water (T1). The $\mathrm{Na} / \mathrm{K}$ ratio is one of the factors closely related to the degree of salt tolerance and it can be used as an index for toxicity of $\mathrm{Na}$ due to the fact that this ion inhibits the activity of enzymes requiring $\mathrm{K}$. Some authors consider that salt tolerance is associated with the maintenance of an adequate supply of $\mathrm{K}$, and the $\mathrm{Na} / \mathrm{K}$ ratio can be used as a criterion for selection of materials sensitive and tolerant to saline stress (TALEISNIK \& GRUNBERG 1994).

$\mathrm{The} \mathrm{Na} / \mathrm{K}$ ratio was higher in the stem of maize plants, with values ranging approximately five times higher than in the leaf blade (Table 3). The retention rates of $\mathrm{Na}$ in stem, measured by the ratio of the concentrations in stem and leaf blade increased with the application of saline water in irrigation, mainly under continuous use of high salinity water (T5). In this treatment the value was 21 times higher than that observed in treatment of low salinity water (T1), while the retention rate of $\mathrm{K}$ did not differ among treatments, with a value around 1.5. These responses suggest the existence of mechanisms of selective retention of ions and support the hypothesis that plants seek an adjustment in relation to concentrations of $\mathrm{Na}$ and $\mathrm{K}$ (AQUINO et al., 2007). According to these authors, the sodium ions absorbed in excess because of its greater availability in saline medium can contribute to osmotic adjustment in plant tissue, however, depending on its concentration may cause toxicity, inhibiting the growth and physiological processes.

Changes in $\mathrm{Na} / \mathrm{K}$ ratio and retention rates in stem of these ions show that the continued use of highly saline water causes changes in mineral balance, which may have consequences on growth and yield. On the other hand, the cyclical use of waters with different salinities reduces negative impacts on the mineral nutrition of plants, particularly with regard to the accumulation of potentially toxic ions and the $\mathrm{Na}$ / $\mathrm{K}$ ratio in the shoots (Table 3 ). However, the changes in mineral balance caused by irrigation with saline water did not influence crop yield during the 2009/2010 crop cycle. This may be due to at least in part, to improved climatic conditions resulting in greater precipitation in the months of December and January, which resulted in the alleviation of osmotic effects of salinity.

\section{CONCLUSION}

The use of saline water in a cyclic way allows the replacement of about $50 \%$ of low salinity water in irrigation, without negative impacts on maize yield, and caused decrease in accumulation of potentially toxic ions $(\mathrm{Na}$ and $\mathrm{Cl}$ ) and improvement in the $\mathrm{Na} / \mathrm{K}$ ratio in the shoots of maize plants.

\section{ACKNOWLEDGMENTS}

The authors are grateful to "Conselho Nacional de Desenvolvimento Científico e Tecnológico - CNPq”, Brazil, INCTSal and "Fundação Cearense de Apoio ao Desenvolvimento Científico e Tecnológico", for financial support.

\section{REFERENCES}

AQUINO, A.J.S. et al. Crescimento, partição de matéria seca e retenção de $\mathrm{Na}^{+}, \mathrm{K}^{+}$e $\mathrm{Cl}^{-}$em dois genótipos de sorgo irrigados com águas salinas. Revista Brasileira de Ciência do Solo, v.31, n.5, p.961-971, 2007. Available from: <http://www.scielo.br/ s c ie lo.ph p s c ript $=$ s ci_art text \& pid = S $0100-$ $6832007000500013 \& \operatorname{lng}=$ pt\&nrm=iso\&tlng=pt $>$. Accessed: Apr. 26, 2010. doi: 10.1590/S0100-06832007000500013.

AZEVEDO NETO, A.D.; TABOSA, J.N. Estresse salino em plântulas de milho: parte II. Distribuição dos macronutrientes catiônicos e 
suas relações com o sódio. Revista Brasileira Engenharia Agrícola e Ambiental, v.4, n.2, p.165-171, 2000. Available from: $<$ www.scielo.br/scielo.php?script $=$ sci_issues\&pid $=1415$ 4366\&lng=en\&nrm=iso>. Accessed: Mar. 26, 2010.

BEZERRA, A.K.P. et. al. Rotação cultural feijão caupi/milho utilizando-se águas de salinidades diferentes. Ciência Rural, v.40, p.1075-1082, 2010. Available from: <http://www.scielo.br/ scielo.php?pid=0103-8478\&script $=$ sci_serial $>$. Accessed: Mar. 4, 2011 .

BLANCO, F.F. et al. Growth and yield of corn irrigated with saline water. Scientia Agricola, v.65, p.574-580, 2008. Available from: $<$ http://www.scielo.br/scielo.php?script=sci_serial\&pid=01039016\&lng=en\&nrm=iso>. Accessed: Mar. 26, 2010.

CHAUHAN, S.K. et al. Effect of cyclic use and blending of alkali and good quality waters on soil properties, yield and quality of potato, sunflower and sesbania. Irrigation Science, v.26, p.81-89, 2007. Available from: <http:// www.springerlink.com.w10016.dotlib.com.br/content/ 0342 7188/26/1/>. Accessed: Mar. 26, 2010. doi. 10.1007/s00271007-0074-z.

DOORENBOS, J.; KASSAM, A.H. Efeito de água no rendimento das culturas. Campina Grande: UFPB, 1994. 306p. (FAO Estudos de Irrigação e Drenagem, 33).

GARCIA, G.O. et al. Índices fisiológicos, crescimento e produção de milho irrigado com água salina. Irriga. v.12, n.3, p.307325, 2007. Available from: <http://200.145.140.50/index.php/ irriga>. Accessed: Apr. 26, 2009

GARCIA, D.M. et al. Supplemental saline drip irrigation applied at different growth stages of two bell pepper cultivars grown with or without mulch in non-saline soil. Agricultural Water Management, v.98, p.893-898, 2011. Available from: <http:/ /www.sciencedirect.com/science/journal/03783774>. Accessed: Ago. 30, 2011.

GHEYI, H.R. et al. Manejo da salinidade na agricultura: estudos básicos e aplicados. Fortaleza: INCTSal, 2010. 485p.

LACERDA, C.F. et al. Soil salinization and maize and cowpea yield in the crop rotation system using saline waters.
Engenharia Agrícola, v.31, n.4, p.663-675, 2011. Available from: 〈http://www.scielo.br/pdf/eagri/v31n4/05.pdf>. Accessed: Mar. 30, 2012.

MALASH, N.M. et al. Effect of irrigation methods, management and salinity of irrigation water on tomato yield, soil moisture and salinity distribution. Irrigation Science, v.26, p.313-323, 2008. Available from: <http://www.springerlink.com.w10016.dotlib.com.br/ content/0342-7188/26/4/>. Accessed: Apr. 26, 2010. doi: 10.1007/ s00271-007-0095-7.

MITTLER, R. Abiotic stress, the field environment and stress combination. Trends in Plant Science, v.11 n.1, p.15-19, 2006. Available from: <http://www.elsevier.com/wps/find/ journaldescription.cws_home/30960/description\#description>. Accessed: Apr. 26, 2010. doi:10.1016/j.tplants.2005.11.002.

MURTAZA, G. et al. Irrigation and soil management strategies for using saline-sodic water in a cotton-wheat rotation. Agricultural Water Management, v.81, p.98-114, 2006. Available from: <http://www.sciencedirect.com/science/journal/ 03783774>. Accessed: Apr. 26, 2010. doi:10.1016/ j.agwat.2005.03.003.

NEVES, A.L.R. et al. Monitoring soil coverage and yield of cowpea furrow irrigated with saline water. Revista Ciência Agronômica, v.41, p.59-66, 2010. Available from: <http:// www.ccarevista.ufc.br/seer/index.php/ccarevista/issue/view/21>. Accessed: Apr. 26, 2010.

SILVA, F.J.A. et al. Águas subterrâneas no Ceará - poços instalados e salinidade. Revista Tecnologia, v.28, n.2, p.136$159,2007$.

TALEISNIK, E.; GRUNBERG, K. Ion balance in tomato cultivars differing in salt tolerance. I. Sodium and potassium accumulation and fluxes under moderate salinity. Physiologia Plantarum, v. 92, p. $528-534,1994$.

YADAV, R.K. et al. Fodder production and soil health with conjunctive use of saline and good quality water in ustipsamments of a semi-arid region. Land Degradation \& Development, v.18, p.153-161, 2007. Available from: <http:/ /onlinelibrary.wiley.com/journal/10.1002/\%28ISSN\%291099145X/issues>. Accessed: Apr. 26, 2010. doi: 10.1002/ldr.776. 